\title{
Bacterial arthritis of native joints can be successfully managed with needle arthroscopy
}

\author{
Tobias Stornebrink 1,2,3, Stein J. Janssen 1,2,3, Arthur J. Kievit ${ }^{1,2,3}$, Nathaniel P. Mercer ${ }^{4}$, John. G. Kennedy ${ }^{4}$, \\ Sjoerd A. S. Stufkens ${ }^{1,2,3}$ and Gino M. M. J. Kerkhoffs ${ }^{1,2,3^{*}}$
}

\begin{abstract}
Purpose: To assess the feasibility of needle arthroscopy for management of suspected bacterial arthritis in native joints.

Methods: During a pilot period, patients presenting with symptoms suggestive of native joint bacterial arthritis were eligible for initial management with needle arthroscopy. Procedures were performed in the operating theatre or at the patient bedside in the emergency department or inpatient ward. As our primary outcome measure, it was assessed whether needle arthroscopic lavage resulted in a clear joint. In addition, the need for conversion to standard arthroscopy or arthrotomy, the need for conversion from local to general anaesthesia, complications and the need for additional surgical intervention at follow-up during admission were recorded.

Results: Eleven joints in 10 patients (four males, age range 35 - 77) were managed with needle arthroscopy. Needle arthroscopic lavage resulted in a clear joint in all cases. Conversion to standard arthroscopy or arthrotomy was not needed. Seven procedures were performed at the patient bedside using local anaesthesia. These procedures were well tolerated and conversion to general or spinal anaesthesia was not required. There were no procedure complications. One patient received multiple needle arthroscopic lavages. No further surgical interventions beside the initial needle arthroscopic lavage were required for successful management in other cases.
\end{abstract}

Conclusions: Needle arthroscopy can be a feasible tool in the initial management of complaints suggestive for native joint bacterial arthritis, providing an effective, quick and well-tolerable intervention in the operating theatre or at the patient bedside, with the potential to relief health systems from need for scarce operating theatre time.

Keywords: NanoScope, Needle arthroscopy, Bacterial arthritis

\section{Background}

A suspected bacterial infection of a native joint - so called septic or bacterial arthritis - requires urgent management to control potential life-threatening sepsis and reduce the risk of cartilage destruction. Initial management of a suspected bacterial arthritis consists of joint drainage, followed by antibiotic therapy [7]. Several options are commonly used to drain a bacterially infected

\footnotetext{
*Correspondence: g.m.kerkhoffs@amsterdamumc.nl

${ }^{1}$ Department of Orthopedic Surgery, Amsterdam UMC, University of Amsterdam, Amsterdam Movement Sciences, Meibergdreef 9, 1105 AZ Amsterdam, The Netherlands

Full list of author information is available at the end of the article
}

joint, ranging from (repeated) needle aspiration to open surgical synovectomy and lavage. Standard arthroscopy is commonly used in daily practice in Europe, allowing for diagnostic joint inspection and therapeutic lavage. However, arthroscopy requires anaesthesia and an operating room, potentially causing diagnostic and treatment delay as well as anaesthesia-related complications and posing a logistic burden on the healthcare system.

Recent technical innovation offers the possibility of 1.9- $\mathrm{mm}$ diameter arthroscopy with a disposable and portable arthroscope [13]. This needle arthroscopy uses a tablet for image processing whilst the needle arthroscope can be connected to syringes for distention and 
rinsing of the joint. Hence, only limited tools are needed (no arthroscopy tower), allowing it to be taken out of the operating theatre and moved around the hospital as a hand-held system. In addition, only small $(2.3-\mathrm{mm})$ portals are required, which are expected to be acceptable for the patient under local anaesthesia [11-13].

These above-mentioned potential benefits of needle arthroscopy might make it very suitable for the (initial) management of suspected native joint bacterial arthritis. Without the need for an operating theatre, the procedure can be performed as a bedside procedure in an office procedure room, emergency department (ER) or inpatient ward. This would expedite diagnosis, treatment, and potentially patient recovery. This possible use and these advantages of needle arthroscopy have not yet been demonstrated - as far as we know. Therefore, this pilot study evaluates first clinical experience with needle arthroscopy for (initial) management of suspected native joint bacterial arthritis.

\section{Methods}

This observational pilot study was conducted in agreement with the 1964 Helsinki Declaration and its later amendments and falls under approval by the Medical Ethics Committee of the University of Amsterdam, with reference number MEC 08/326. In a pilot period between January 2020 and December 2020, all adult (18 years of age or older) patients presenting to the Orthopedic Surgery department of our university hospital (Amsterdam UMC, Amsterdam, The Netherlands) with a clinical suspicion of bacterial arthritis of a native joint were eligible for initial management using needle arthroscopy. The pilot did not alter our standard management of suspected bacterial arthritis, except for the lavage being performed with a needle arthroscope under local portal anaesthesia, instead of a regular arthroscope under general or locoregional anaesthesia. Whether needle arthroscopy was used instead of standard arthroscopy was left to the discretion of the orthopedic surgeon on call. Patients with a periprosthetic joint infection or a foreign body (e.g. surgical screw or suture anchor) in the affected joint were not eligible for inclusion.

\section{Needle arthroscope}

A 1.9-mm diameter, disposable arthroscope was used for all procedures (NanoScope, Arthrex, Naples, FL). The camera uses an optic chip at the distal end of its camera tube instead of an inner series of conventional rod-lenses. This chip-on-tip technology allows for a semi-rigid frame that remains durable at a diameter of $1.9 \mathrm{~mm}$. In combination with a tailored cannula, the total outer diameter of the arthroscopy portal measures $2.3 \mathrm{~mm}$. Imaging is processed by a tablet-like control unit. Arthroscopic instruments, including a 2-mm diameter probe (NanoProbe, Arthrex, Naples, FL), a 2-mm diameter biter (NanoBiter, Arthrex, Naples, $\mathrm{FL}$ ), a 2-mm diameter grasper (NanoGrasper, Arthrex, Naples, FL) and a shaver (blades of 2 to 3-mm diameter) are available, allowing for therapeutic interventions during needle arthroscopy.

\section{Procedure}

Procedures were performed in the operating theatre or at the patient bedside in the emergency department or inpatient ward. Figure 1 explains all steps in detail, including materials used in each step. Sterility measures included local skin disinfection, surgical draping and sterile gloves. In case the procedure was performed in the operating theatre, standard general or regional anaesthesia was administered. At the patient bedside, local anaesthesia was used. In case of local anaesthesia, $10 \mathrm{cc}$ lidocaine $2 \%$ was injected along the entire tract of planned portals and into the joint cavity. Two portals were used - one for inflow and arthroscope introduction and one for outflow. They were created at standard, joint specific locations. After a 2-mm skin incision and blunt introduction of the cannula, intra-articular fluid or pus was aspirated through the cannula and sent for culture. Subsequently, the needle arthroscope was inserted. A $50 \mathrm{cc}$ syringe was connected to the cannula, and saline was used for distention and lavage. The outflow portal was created under intra-articular visualization and consisted of a large-bore (14G) IV-infusion needle. At the end of the procedure, the incisions were closed with sterile wound closure strips and a bandage, and empirical antibiotic treatment was started.

\section{Outcome measures}

We noted whether needle arthroscopic lavage was deemed successful, and defined this as: successful lavage until macroscopically clear saline and no remaining loculations of pus present upon careful inspection of the joint. In addition, we noted the need for conversion from local anaesthesia to general or regional anaesthesia, the need for conversion from needle arthroscopy to standard arthroscopy or open surgery and occurrence of complications (neurovascular damage, bleeding requiring additional surgery, device failure). Patient follow-up included their entire admission until discharge. During follow-up, it was recorded whether any additional surgical interventions (including needle aspiration, needle arthroscopy, traditional arthroscopy and arthrotomy) were needed to ensure patient recovery. 
A

\begin{tabular}{|l|l|}
\hline & \multicolumn{1}{|c|}{ Materials } \\
\hline & - Assistant \\
- Side table with sterile cover & - Surgical gown \\
을 & - Sterile gloves \\
山 - Safety goggles
\end{tabular}

- Needle arthroscopic control unit

- Shaver control unit and pump

- Disinfectant, e.g. chlorhexidine

- Sterile gauze

- Sterile drape

- 10 cc syringe filled with lidocaine

$2 \%(2 x)$

- $21 \mathrm{G}$ needle

\section{Procedure}

Position all equipment and the assistant according to personal preference. Make sure that the needle arthroscopic control unit and - if used - shaver unit and pump are ready for use. Prepare all materials required for subsequent steps and store on the side table's sterile field. Apply personal protective and sterile equipment.

Disinfect the surgical site as required and apply sterile draping. Make sure the planned inflow and outflow portals remain uncovered.

Anesthetize the entire tract of both portals and inject intra-articular. Make sure the joint capsule is well-anesthetized.

Make a 2-mm skin incision at the inflow porta. Bluntly insert the cannula. Connect the syringe and aspirate to dryness. Disconnect the syringe, empty and reconnect as required. Collect synovial fluid or pus for culture. Leave the cannula inserted.

Insert the camera through the cannula. Attach a stopcock connection tube to the cannula and a full $50 \mathrm{cc}$ syringe to the stopcock. Distend the joint. Insert a 14G infusion needle at the outflow portal under arthroscopic visualization. Remove the needle from its cannula. Attach a stopcock connection tube to the cannula and an empty 50cc syringe to the stopcock. Perform needle arthroscopic lavage, aspirate with the outflow syringe. Ask the assistant to refill the inflow syringe and to empty the outflow syringe. Inspect the entire joint cavity and make sure any loculations of pus or debris are addressed. If needed, the outflow cannula can be replaced with the shaver for removal of fibrotic tissue. Replace the outflow portal with the grasper to take an arthroscopically guided soft-tissue biopsy. If preferred, an arthroscopic pump can be used for irrigation instead of the inflow syringe.

- Sterile skin closure strips

- Pressure bandage

Aspirate the joint to dryness, through either one of the portals. Close the skin incisions with sterile skin

\section{B}
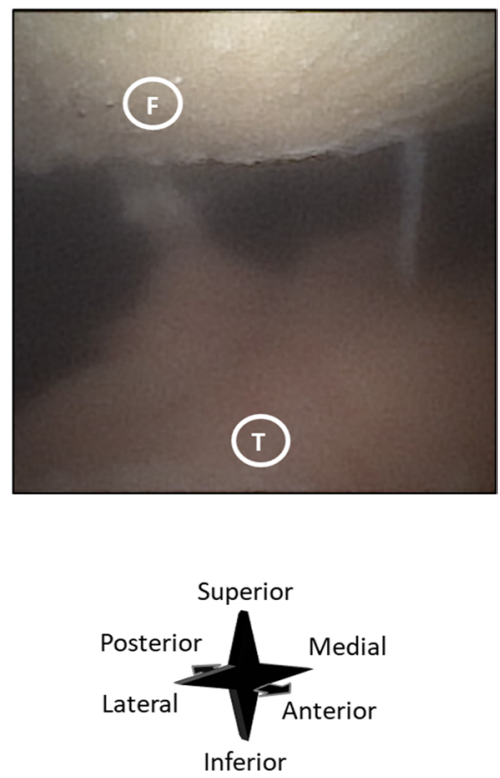

C

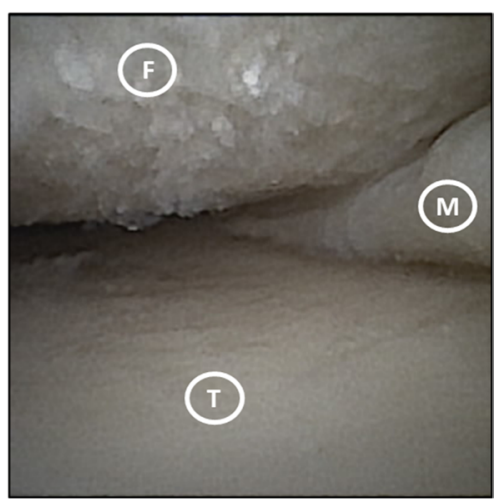
closure strips. Dispose of all materials as required.

Fig. 1 With a stepwise approach (A), needle arthroscopic lavage of a suspected native joint bacterial arthritis (B) results in a clear joint (C). Local anaesthesia is described, yet all other steps equally apply to general or regional anaesthetic procedures. Intra-articular images $\mathbf{B}$ (before lavage) and C (after lavage) were taken from the same anterolateral portal in the same right knee. F indicates the femur, T indicates the tibia, $\mathrm{M}$ indicates the meniscus

\section{Results}

Eleven joints in 10 patients were suspected of a bacterial infection and treated using needle arthroscopy upon presentation. Patient age ranged from 35 to 77 years; four patients were male (Table 1). Needle arthroscopy led to successful lavage in all cases (Fig. 1), without a need for conversion to standard arthroscopy or arthrotomy. Eight initial procedures were performed under local anaesthesia in the ER (three cases) and inpatient ward (five cases). Local anaesthesia resulted 
Table 1 Patient characteristics

\begin{tabular}{|c|c|c|c|c|c|c|}
\hline Case & $\begin{array}{l}\text { Age at } \\
\text { presentation }\end{array}$ & Gender & Comorbidities & Affected joint & Clinical features at presentation & Lab at presentation \\
\hline \multirow[t]{2}{*}{1} & \multirow[t]{2}{*}{65} & \multirow[t]{2}{*}{ Male } & \multirow{2}{*}{$\begin{array}{l}\text { Gout, seronegative spondyloarthritis, } \\
\text { hypertension }\end{array}$} & \multirow[t]{2}{*}{ Wrist } & $\mathrm{T}: 35.7$ & L: 13.0 \\
\hline & & & & & $\begin{array}{l}\text { Local joint: pain, function loss, swell- } \\
\text { ing, warmth, redness }\end{array}$ & CRP: 36 \\
\hline \multirow[t]{2}{*}{2} & \multirow[t]{2}{*}{69} & \multirow[t]{2}{*}{ Female } & \multirow[t]{2}{*}{ COPD } & \multirow[t]{2}{*}{ Knee } & $\mathrm{T}: 36.8$ & L: 14.6 \\
\hline & & & & & $\begin{array}{l}\text { Local joint: pain, function loss, swell- } \\
\text { ing, warmth }\end{array}$ & CRP: 226 \\
\hline \multirow[t]{2}{*}{3} & \multirow[t]{2}{*}{69} & \multirow[t]{2}{*}{ Female } & \multirow[t]{2}{*}{ COPD } & \multirow[t]{2}{*}{ Knee } & $\mathrm{T}: 37.4$ & L: 14.6 \\
\hline & & & & & $\begin{array}{l}\text { Local joint: pain, function loss, swell- } \\
\text { ing, warmth }\end{array}$ & CRP: 301 \\
\hline \multirow[t]{2}{*}{4} & \multirow[t]{2}{*}{35} & \multirow[t]{2}{*}{ Male } & \multirow{2}{*}{$\begin{array}{l}\text { Kidney failure, hypertension, } 26 \text { days } \\
\text { after conservatively treated ipsilat- } \\
\text { eral patellar fracture }\end{array}$} & \multirow[t]{2}{*}{ Knee } & $\mathrm{T}: 36.6$ & $\mathrm{~L}: 8.7$ \\
\hline & & & & & $\begin{array}{l}\text { Local joint: pain, function loss, swell- } \\
\text { ing, warmth }\end{array}$ & CRP: 169 \\
\hline \multirow[t]{2}{*}{5} & \multirow[t]{2}{*}{77} & \multirow[t]{2}{*}{ Female } & \multirow[t]{2}{*}{ Rheumatoid arthritis, diabetes type 2} & \multirow[t]{2}{*}{ Ankle } & $\mathrm{T}: 37.6$ & $\mathrm{~L}: 12.0$ \\
\hline & & & & & $\begin{array}{l}\text { Local joint: pain, function loss, swell- } \\
\text { ing, warmth }\end{array}$ & CRP: 81 \\
\hline \multirow[t]{2}{*}{6} & \multirow[t]{2}{*}{66} & \multirow[t]{2}{*}{ Male } & \multirow{2}{*}{$\begin{array}{l}\text { Hypertension, admitted at presenta- } \\
\text { tion on account of infected vascular } \\
\text { implant }\end{array}$} & \multirow[t]{2}{*}{ Knee } & $\mathrm{T}: 37.5$ & $\mathrm{~L}: 12.9$ \\
\hline & & & & & $\begin{array}{l}\text { Local joint: pain, function loss, swell- } \\
\text { ing }\end{array}$ & CRP: 137 \\
\hline \multirow[t]{2}{*}{7} & \multirow[t]{2}{*}{37} & \multirow[t]{2}{*}{ Female } & \multirow[t]{2}{*}{ Rheumatoid arthritis } & Knee & $\mathrm{T}: 36.7$ & $\mathrm{~L}: 14.0$ \\
\hline & & & & & $\begin{array}{l}\text { Local joint: pain, function loss, swell- } \\
\text { ing, warmth }\end{array}$ & CRP: 346 \\
\hline 8 & 68 & Female & Rheumatoid arthritis, osteoarthritis, & Shoulder & $\mathrm{T}: 38.8$ & L: 7.9 \\
\hline & & & $\begin{array}{l}\text { stroke, diabetes type 2, atrial fibrilla- } \\
\text { tion, heart failure }\end{array}$ & & $\begin{array}{l}\text { Local joint: Pain, loss of function, } \\
\text { swelling, warmth }\end{array}$ & CRP: 161 \\
\hline 9 & 58 & Female & Kidney failure, hypertension, Sjogren's & Knee & $\mathrm{T}: 37.0$ & $L: 7.3$ \\
\hline & & & syndrome, gout & & $\begin{array}{l}\text { Local joint: pain, function loss, swell- } \\
\text { ing }\end{array}$ & CRP: 270 \\
\hline 10 & 71 & Female & Peripheral arterial occlusive disease, & Knee & $\mathrm{T}: 37.0$ & L: 14.9 \\
\hline & & & hypertension, atrial fibrillation & & $\begin{array}{l}\text { Local joint: pain, loss of function, } \\
\text { swelling, warmth, redness }\end{array}$ & CRP: 183 \\
\hline 11 & 54 & Male & Transtibial amputation (Left), hyper- & Knee & $\mathrm{T}: 37.1$ & $\mathrm{~L}: 25.3$ \\
\hline & & & tension, diabetes type 1 & & $\begin{array}{l}\text { Local joint: pain, loss of function, } \\
\text { swelling, warmth, redness }\end{array}$ & CRP: 322 \\
\hline
\end{tabular}

$T$ denotes temperature in degrees Celsius, $L$ denotes the leucocyte count times $10^{9} / \mathrm{L}, C R P$ denotes the C-reactive protein in $\mathrm{mg} / \mathrm{L}$

in a tolerable procedure for all these patient and conversion to regional or general anaesthesia was not required. No procedure related complications occurred. One patient died during admission due to a massive intra-cranial bleeding during chemical thrombolysis on account of critical limb ischemia, for which the patient was initially admitted. Death occurred four days after the needle arthroscopic intervention, and complaints of the affected joint had improved. Synovial fluid cultured positive for a micro-organism in three cases (Table 2). Cultures remained negative in remaining patients. All patients were admitted for intra-venous antibiotic therapy. One patient required two repeated needle arthroscopic lavages due to persistent pain. These additional procedures were both performed in the OR-recovery room, with a single shot femoral block as only anaesthetic. Surgical intervention in addition to needle arthroscopy was not required in remaining cases and all patients were successfully discharged.

\section{Discussion}

The main finding of this study was that needle arthroscopy could be successfully used as the initial step in the management of a suspected bacterial arthritis of a native joint. Without a need to convert to standard arthroscopy or arthrotomy, needle arthroscopic lavage resulted in a macroscopically clear joint in all cases. Procedures were successfully performed at the patient bedside in the ER and inpatient ward with local administration of lidocaine as the only anaesthetic. There were no complications and 
Table 2 Procedure characteristics and outcome

\begin{tabular}{|c|c|c|c|c|c|}
\hline Case & Anaesthesia & Procedure location & Complications & $\begin{array}{l}\text { Additional surgery } \\
\text { required during } \\
\text { admission }\end{array}$ & Micro-organism cultured \\
\hline 1 & General & OR & No & No & No \\
\hline 2 & Local & ER & No & No & No \\
\hline 3 & Local & Inpatient ward & No & No & No \\
\hline 4 & General & OR & No & No & No \\
\hline 5 & Local & ER & No & No & No \\
\hline 6 & Local & Inpatient ward & No & No & No \\
\hline 7 & General & OR & No & No & Streptococcus agalactiae \\
\hline 8 & Local & Inpatient ward & No & No & No \\
\hline 9 & Local & Inpatient ward & No & No & S. Aureus \\
\hline 10 & Local & Inpatient ward & $\begin{array}{l}\text { Yes, not related to the suspected bacte- } \\
\text { rial arthritis or needle arthroscopic } \\
\text { procedure }\end{array}$ & No & No \\
\hline 11 & Local & ER & No & $\begin{array}{l}\text { Yes, two additional } \\
\text { needle arthro- } \\
\text { scopic lavages } \\
(11.2 \& 11.3)\end{array}$ & Streptococcus agalactiae \\
\hline 11.2 & Single shot femoral block & Recovery room & No & $"$ & $"$ \\
\hline 11.3 & Single shot femoral block & Recovery room & No & $"$ & " \\
\hline
\end{tabular}

there was no need for further surgical intervention or needle aspiration.

Currently, the initial management of suspected bacterial arthritis includes either surgical lavage or repeated arthrocentesis [2]. This pilot study showed the feasibility of needle arthroscopy in reaping the benefits of both approaches. Intra-articular visualization and 2-mm diameter instruments allow for thorough diagnostic inspection of the joint, irrigation with large amounts of fluids, identification and removal of localized collections of pus and debris - as all propagated by proponents of a surgical approach to suspected bacterial arthritis. Yet simultaneously, it is a quick procedure that can be performed at the patient bedside under local anaesthesia, without causing extensive soft-tissue trauma - all advantages known to arthrocentesis as well.

Local anaesthesia with lidocaine was sufficient for a well-tolerable intervention. Needle arthroscopy has been successfully performed under local anaesthesia before [17], and various interventional techniques are emerging - including repair of cruciate ligaments and meniscal tears $[4,14]$. Yet, whether more extensive debridement including synovectomy is tolerable for the patient as well, is a subject for future research. Being able to use only local anaesthesia may be beneficial especially in the setting of suspected bacterial arthritis - an event occurring predominantly in children and older adults - as older age, acute surgery and sepsis are all risk factors for anaesthesia-related complications $[3,6,10]$.
In the past, a move from the operating theatre to the patient bedside has resulted in effective and safe surgery, with happier patients and at lower costs [15]. Eliminating the need for conventional surgery can have an especially large impact in the acute care setting, where surgical costs form a substantial proportion of total costs of care [5]. In addition, the need for general anaesthesia and an operating theatre may delay treatment due to pre-anaesthetic tests that have to be conducted or a scarcity of resources - with the current COVID-19 pandemic highlighting the relevance of scarcity and even resulting in scoring systems to distribute scarce urgent surgical care $[8,9]$. Avoiding treatment delay is especially important in patients with bacterial arthritis, where only prompt intervention can avoid morbidity and even mortality.

Lavage saline was administered through the camera portal. That is, saline travelled between the inner cannula wall $(2.2-\mathrm{mm})$, and the outer camera wall $(1.9-\mathrm{mm})$. A second portal was created for outflow. The diameter of the inflow portal was substantially smaller compared to standard arthroscopy, which decreases the intra-articular passage speed of irrigation saline [16]. Inflow proved to generate sufficient pressure for joint distention similar to standard arthroscopy. Yet, the time that was required to pass a sufficient amount of saline indeed seemed longer compared standard arthroscopy. Nonetheless, evidence suggests that the rinsing pressure that can be generated with syringes is sufficient for adequate lavage of a bacterially infected surface [1]. In an in-vitro setting, small-bore 


\begin{tabular}{|c|c|c|c|c|}
\hline Phase I: Presentation & \multicolumn{2}{|c|}{ Phase II: Bedside needle arthroscopy } & \multicolumn{2}{|c|}{ Phase III: Monitoring } \\
\hline $\begin{array}{l}\text { A patient reports with signs of bacterial } \\
\text { arthritis. Standard basic diagnostics are } \\
\text { performed, which includes imaging and } \\
\text { blood tests. }\end{array}$ & \multicolumn{2}{|c|}{$\begin{array}{l}\text { In case of persistent suspicion of bacterial } \\
\text { arthritis, a needle arthroscopic procedure is } \\
\text { performed at the patient bedside, using local } \\
\text { anesthetics. The joint is inspected and a needle } \\
\text { arthroscopic lavage is performed. An antibiotics } \\
\text { regimen is started as indicated and the patient is } \\
\text { admitted if needed. }\end{array}$} & \multicolumn{2}{|c|}{$\begin{array}{l}\text { Protocolled parameters are used to monitor the patients' } \\
\text { clinical status. In case of deterioration, additional surgical } \\
\text { procedures may be indicated, e.g. open or standard } \\
\text { arthroscopic lavage. In case of recovery, the patient is } \\
\text { discharged from care, and follow-up according to local } \\
\text { protocol is started. }\end{array}$} \\
\hline $\begin{array}{ll}\text { Patient inflow } & \text { Step 1: } \\
\text { Diagnostics }\end{array}$ & Option A & $\begin{array}{l}\text { Step 2.A: Needle } \\
\text { arthroscopy }\end{array}$ & Option Q: Deterioration & $\begin{array}{l}\text { Step 3.Q: } \\
\text { Intervention }\end{array}$ \\
\hline \multirow[t]{3}{*}{$\begin{array}{l}\text { Patient reports } \\
\text { with signs of } \\
\text { bacterial } \\
\text { arthritis }\end{array}$} & $\begin{array}{l}\text { Bacterial } \\
\text { arthritis is } \\
\text { suspected }\end{array}$ & $\begin{array}{l}\text { Needle arthroscopic } \\
\text { lavage at the patient } \\
\text { bedside } \\
\text { - Start antibiotics } \\
\text { - Admission to } \\
\text { inpatient ward if } \\
\text { needed }\end{array}$ & $\begin{array}{l}\text { Based on predefined } \\
\text { parameters, e.g.: } \\
\text { a. Lab parameters } \\
\text { b. Pain } \\
\text { c. Range of motion } \\
\text { d. Persistent fever } \\
\text { e. Judgement by treating } \\
\quad \text { surgeon }\end{array}$ & $\begin{array}{l}\text { Additional } \\
\text { intervention at } \\
\text { surgeon } \\
\text { discretion, e.g. } \\
\text { standard } \\
\text { arthroscopic } \\
\text { lavage }\end{array}$ \\
\hline & Option B & $\begin{array}{l}\text { Step 2.B: Standard } \\
\text { care }\end{array}$ & Option R: Recovery & $\begin{array}{l}\text { Step 3.R: } \\
\text { Discharge }\end{array}$ \\
\hline & $\begin{array}{c}\text { Bacterial } \\
\text { arthritis is } \\
\text { refuted }\end{array}$ & $\begin{array}{l}\text { - Standard care as } \\
\text { applicable }\end{array}$ & Patient recovers & $\begin{array}{l}\text { - Patient is } \\
\text { discharged } \\
\text { - Follow-up } \\
\text { according to } \\
\text { local protocol }\end{array}$ \\
\hline
\end{tabular}

Fig. 2 Needle arthroscopy can successfully be used as the initial intervention in suspected bacterial arthritis of a native joint. Incorporating needle arthroscopy in the management protocol may result in less use of surgical interventions as standard arthroscopy or open surgery, whilst standard surgery can always be deployed as a back-up intervention for non-improving patients

syringe irrigation of bacterially infected biological surfaces - including cancellous bone - provided effective reduction of the bacterial load, statistically equal to a large-bore jet lavage system [1]. In our pilot patients, lavage resulted in a clear joint in all cases, without a need for further surgical intervention at a later stage during admission. This underscores the feasibility of bedside needle arthroscopy as a minimally invasive, quick and effective first intervention in acute arthritis. Nevertheless, we do recommend to consider that needle arthroscopic lavage may have been inferior compared to what we are used to from standard arthroscopy in case of a non-recovering patient.

This pilot study should be interpreted in light of its limitations. Rather than providing proof of effective treatment, the limited number of patients merely indicates the feasibility of needle arthroscopy in the initial management of suspected native joint bacterial arthritis. Only knee, wrist, ankle and shoulder cases were treated so far. Needle arthroscopic treatment of other joints as the hip may be more difficult. A microorganism was cultured in the synovial fluid in only three out of 11 cases (27\%). A negative culture alone cannot rule out bacterial arthritis in case of high clinical suspicion [2], which applied to all included patients. Nevertheless, the results of this pilot study should be transferred to culture-proven cases with care until examined in a sufficiently powered sequel study.

We suggest using needle arthroscopy as the initial step in the management of suspected bacterial arthritis of a native joint. Figure 2 provides a potential management protocol. Following initial needle arthroscopic lavage, an antibiotic regimen according to local protocol should commence. At surgeon discretion, patients may further be treated with repeated needle arthroscopy or arthrocentesis to provide additional relief and monitor disease activity. In case of disease progression - e.g. a persistent fever, increasing pain, non-improving range of motion or deteriorating lab parameters - more invasive surgery should be considered. A prospective evaluation of this management protocol was started in our university medical centre. This prospective study will further scrutinize the benefit of needle arthroscopy in treating native joint bacterial arthritis.

\section{Conclusions}

This feasibility study indicates that needle arthroscopy could be a successful tool in the initial management of complaints suggestive for native joint bacterial arthritis, providing an effective, quick and well-tolerable intervention in the operating theatre or at the patient bedside. It has the potential to decrease demand for scarce operating 
theatre time, which can subsequently be more effectively allocated to other indications. Patients unfit for surgery at the time of suspected diagnosis can be treated more promptly.

\section{Acknowledgements \\ Not applicable.}

\section{Authors' contributions}

All authors contributed to the study and manuscript, revised the manuscript critically and gave their final approval for submission and publication.

\section{Funding}

The Department of Orthopedic Surgery from the Amsterdam UMC was supported with an unrestricted research grant from Arthrex GmbH. The funding body had no role in the design of the study and collection, analysis, and interpretation of data, nor in writing the manuscript.

\section{Availability of data and materials}

The datasets used and/or analysed during the current study are available from the corresponding author on reasonable request.

\section{Declarations}

\section{Ethics approval and consent to participate}

The study was conducted in agreement with the 1964 Helsinki Declaration and its later amendments and was approved by Medical Ethics Committee of the University of Amsterdam, with reference number MEC 08/326.

\section{Consent for publication}

Not applicable.

\section{Competing interests}

Dr. Kennedy reports consultancy fees from Arthrex, outside the submitted work.

\section{Author details}

${ }^{1}$ Department of Orthopedic Surgery, Amsterdam UMC, University of Amsterdam, Amsterdam Movement Sciences, Meibergdreef 9, 1105 AZ Amsterdam, The Netherlands. ${ }^{2}$ Academic Center for Evidence Based Sports Medicine (ACES), Amsterdam, The Netherlands. ${ }^{3}$ Amsterdam Collaboration for Health and Safety in Sports (ACHSS), International Olympic Committee (IOC) Research Center Amsterdam UMC, Amsterdam, The Netherlands. ${ }^{4}$ Department of Orthopaedic Surgery, NYU Langone Health, New York, NY, USA.

Received: 28 May 2021 Accepted: 4 August 2021

Published online: 24 August 2021

\section{References}

1. Bahrs C, Schnabel M, Frank T, Zapf C, Mutters R, Garrel TV (2003) Lavage of contaminated surfaces: an in vitro evaluation of the effectiveness of different systems. J Surg Res 112:26-30
2. Coakley G, Mathews C, Field M, Jones A, Kingsley G, Walker D et al (2006) BSR \& BHPR, BOA, RCGP and BSAC guidelines for management of the hot swollen joint in adults. Rheumatology (Oxford) 45:1039-1041

3. Cooper C, Cawley MI (1986) Bacterial arthritis in an English health district: a 10 year review. Ann Rheum Dis 45:458

4. Daggett MC, Busch K, Ferretti A, Monaco E, Bruni G, Saithna A (2021) Percutaneous anterior cruciate ligament repair with needle arthroscopy and biological augmentation. Arthrosc Tech 10:e289-e295

5. Fakhry SM, Martin B, Al Harakeh H, Norcross ED, Ferguson PL (2013) Proportional costs in trauma and acute care surgery patients: dominant role of intensive care unit costs. J Am Coll Surg 216:607-614

6. Harris M, Chung F (2013) Complications of general anesthesia. Clin Plast Surg 40:503-513

7. Mathews CJ, Weston VC, Jones A, Field M, Coakley G (2010) Bacterial septic arthritis in adults. Lancet 375:846-855

8. Prachand VN, Milner R, Angelos P, Posner MC, Fung JJ, Agrawal N, et al (2020) Medically necessary, time-sensitive procedures: scoring system to ethically and efficiently manage resource scarcity and provider risk during the COVID-19 pandemic. J Am Coll Surg. https://doi.org/10.1016/j. jamcollsurg.2020.04.011

9. Ricci WM, Brandt A, McAndrew C, Gardner MJ (2015) Factors affecting delay to surgery and length of stay for patients with hip fracture. J Orthop Trauma 29:e109-e114

10. Sigurdsson GH, McAteer E (1996) Morbidity and mortality associated with anaesthesia. Acta Anaesthesiol Scand 40:1057-1063

11. Stornebrink T, Altink JN, Appelt D, Wijdicks CA, Stufkens SAS, Kerkhoffs G (2020) Two-millimetre diameter operative arthroscopy of the ankle is safe and effective. Knee Surg Sports Traumatol Arthrosc. https://doi.org/10. 1007/s00167-020-05889-7

12. StornebrinkT, Emanuel KS, Shimozono Y, Karlsson J, Kennedy JG, Kerkhoffs GMMJ (2020) A change in scope: redefining minimally invasive. Knee Surg Sports Traumatol Arthrosc. https://doi.org/10.1007/ s00167-020-05898-6

13. StornebrinkT, Stufkens SAS, Appelt D, Wijdicks CA, Kerkhoffs G (2020) 2-Mm diameter operative tendoscopy of the tibialis posterior, peroneal, and Achilles tendons: a cadaveric study. Foot Ankle Int 41:473-478

14. StornebrinkT, van Dijck AHE, Douven D, Kerkhoffs G (2021) Needle arthroscopic all-inside repair of meniscal tears under local anesthesia. Arthrosc Tech. in press

15. Van Demark RE, Becker HA, Anderson MC, Smith VJS (2018) Wide-awake anesthesia in the in-office procedure room: lessons learned. Hand 13:481-485

16. Xu Y, Lin H, Zhu P, Zhou W, Han Y, Zheng Y et al (2013) A comparative study between use of arthroscopic lavage and arthrocentesis of temporomandibular joint based on computational fluid dynamics analysis. PLoS One 8:e78953

17. Zhang K, Crum RJ, Samuelsson K, Cadet E, Ayeni OR, de Sa D (2019) Inoffice needle arthroscopy: a systematic review of indications and clinical utility. Arthroscopy 35:2709-2721

\section{Publisher's Note}

Springer Nature remains neutral with regard to jurisdictional claims in published maps and institutional affiliations. 